\title{
Effect of adding coconut milk on the physicochemical, proximate, microbial and sensory attributes of «Dahi»
}

\author{
Abdul Matin ${ }^{1}$, Nahidur Rahman ${ }^{1}$, \\ Tanjida Islam', Fisal Bin Haji Ahmed² \\ 1 - Chattogram Veterinary and Animal Sciences University, Khulshi, Chattogram, \\ Bangladesh \\ 2 - Universiti Malaysia Terengganu, Kuala Terengganu, Terengganu, Malaysia
}

\begin{tabular}{l} 
Keywords: \\
Dahi \\
Coconut \\
Cow \\
Milk \\
Quality \\
\hline
\end{tabular}

Article history:

Received

14.03.2020

Received in

revised form

11.06.2020

Accepted

30.06.2020

Corresponding author:

Abdul Matin

E-mail:

abmatinfst@

gmail.com

DOI:

$10.24263 / 2310-$

1008-2020-8-1-6

\section{Abstract}

Introduction. Plant-based or non-dairy milk alternates are the growing trend in newer food product development. Therefore, the present study was conducted to explore the quality and potential of «Dahi» prepared by cow milk and different levels of coconut milk.

Materials and methods. The obtained formulations, A (Control), B, and $\mathrm{C}$ were prepared by mixing cow milk to coconut milk in three different rations (100:0, 50:50, 0:100). The proximate composition, physicochemical, sensorial, and microbial properties were determined to ascertain the quality attributes of the «Dahi» samples. Obtained data were analyzed statistically, and means were compared at $5 \%$ level of significance.

Results and discussion. The results of the physicochemical analysis showed increasing trends in the values for $\mathrm{pH}(4.05-4.33)$, TSS (14.05-14.90), and Sweetness Index (10.60-20.13) while substituting cow milk with coconut milk. There was also a remarkable increase in the proximate values for moisture (82.75$85.20 \%)$, fat $(1.57-3.06 \%)$ and ash $(0.71-2.94 \%)$. The results suggested that coconut milk addition leads to a considerable increase in mineral content as well as unsaturated fatty acids that may promote health benefits. A reverse trend was observed for acidity $(0.64-0.56 \%)$, protein $(3.13-2.98 \%)$ and carbohydrate $(11.85-5.82 \%)$ values in coconut enriched «Dahi». The bacterial counts of all the samples $(4.51-5.34) \times 10^{5} \mathrm{cfu} / \mathrm{ml}$ were within the acceptable standard for fermented dairy products. The results of the current study also demonstrated that the addition of coconut milk significantly improved the «Dahi»s' aroma and consistency. Overall, the acceptability of coconut milk enriched «Dahi» was highly comparable to the control ( $« \mathrm{Dahi} »$ of $100 \%$ cow milk).

Conclusions. Thus, «Dahi» from the coconut milk can be a match-able substitute for the conventional dairy-based «Dahi», which could be particularly advantageous to the lactose-intolerant people and high coconut producing regions. 


\section{Introduction}

«Dahi» is one of the most common fermented food products obtained through the controlled fermentation process of lactose of the milk by mixed culture of lactic acid bacteria, which are classified as probiotics [1]. The anaerobic fermentation of the milk sugar (lactose) causes the characteristic curd and ensures the increased shelf life, microbial safety of the food and also makes food more digestible [2]. In Bangladesh, «Dahi» is more commonly consumed as a desert food item and found as a good source of probiotic lactic acid bacteria that can play major role for beneficial health effects of consumer [3].

Nowadays, allergen, lactose intolerance and calorie concern regarding cow milk induces more preference to vegan diets and has influenced consumers to choose cow milk alternatives [4]. Recent researches are shifting focus to diverse components in fermented dairy products. «Dahi» serves as a good source of vitamin B, protein and calcium content but lacks certain essential nutrients such as high-quality unsaturated lipids, fibers, and antioxidant compounds that are readily found from plant sources. Coconut is a versatile fruit, which is found in most regions of the world, particularly in Southeast Asia [5]. The aqueous emulsion of coconut kernel prepared by hand or mechanical pressing is known as coconut milk. It is a prominent source of dietary protein, energy, calcium, and fat such as myristic acid, oleic acid, lauric acid, linoleic acid, palmitic acid, and capric acid [6]. It is also a rich source of vitamins and minerals [7]. Contrary to widely held opinion, coconut milk exhibits the highest antioxidant activity among goat and cow's milk and may provide many health benefits beyond its nutritional content, due to its fiber and oil content [8,9].

Thus, researchers have urged to develop new dairy foods using a combination of nondairy milk i.e. coconut milk. It can be used as a substrate to produce functional «Dahi» with probiotic properties with enhanced flavor [10]. In the context of the local Bangladeshi market, the availability of fruits and flavored «Dahi» is very rare. Besides, the enhanced flavor of coconut can be functionalized as the addition of value for the existing products in the current market at relatively low cost [9]. Thus, the study was carried out to evaluate the feasibility of the formulation of «Dahi» using coconut milk and to analyze the effects of adding coconut milk on the physicochemical, proximate, microbial and sensory attributes of the product.

\section{Materials and methods}

\section{Raw Materials Procurement}

The coconut fruits were brought from local markets. Raw cow milk and «Dahi», which was used as the starter culture in this study were also purchased from a Superstore of Chattogram city. Potable water was strictly used throughout the study.

\section{Extraction and Preparation of Coconut Milk}

The coconut milk was prepared as the method described by Kolapo and Olubamiwa, [11] with slight modifications. The fresh coconuts used in this study were crushed open and the juice poured and stored in a refrigerator. $1 \mathrm{~kg}$ of coconut flesh was then removed from the shell, grated and homogenized in a blender (Panasonic, MX-AC300) together with the coconut juice for $3 \mathrm{~min}$. It was then passed through a cheese cloth twice, with the volume adjusted to $750 \mathrm{ml}$ and stored in refrigerated condition. The obtained filtrate is termed as coconut milk. The extracted coconut milk was shifted into a jar and pasteurized or heated at $90^{\circ} \mathrm{C}$ for $30 \mathrm{~min}$ and allowable to cool gradually. The temperature was maintained carefully. 


\section{Preparation of «Dahi»}

The «Dahi» was prepared from the blends of cow milk and coconut milk. The mixtures were composed according to different proportions, as shown in Table 1.

Milk blends and their proportions

Table 1

\begin{tabular}{|c|c|c|c|}
\hline Sample codes & $\begin{array}{c}\text { Cow milk } \\
(\mathbf{m L})\end{array}$ & $\begin{array}{c}\text { Coconut milk } \\
(\mathbf{m L})\end{array}$ & $\begin{array}{c}\text { Proportions (Cow milk : } \\
\text { Coconut milk) }\end{array}$ \\
\hline A & 100 & 0 & $100: 0$ \\
\hline B & 50 & 50 & $50: 50$ \\
\hline C & 0 & 100 & $0: 100$ \\
\hline
\end{tabular}

An amount of $8 \%(8.0 \mathrm{~g})$ of sugar was added to each of the blends to sweeten the mixture. Then they were slightly heated and were inoculated with $1 \%(1 \mathrm{~g})$ of the starter culture. All the inoculated milk blends were poured into plastic cups and then placed into an incubator (GSP-9080 MBE, Shanghai, China) at $43^{\circ} \mathrm{C}$ for $6 \mathrm{~h}$ to facilitate fermentation and curd formation. Finally, the cups were placed in a refrigerator at $4{ }^{\circ} \mathrm{C}$ and stored for further analysis. Coded sample A (dahi of $100 \%$ cow milk) was used as the control here in this study.

\section{Determination of Physicochemical Properties}

The $\mathrm{pH}$ of the «Dahi» samples was measured with a pH meter (HI-98107, Hanna Instrument, Italy). Total soluble solids (TSS) were obtained by using a digital refractometer (HI-96811, Hanna Instrument, Italy). Titratable acidity in terms of the \% of lactic acid was measured, according to Hamad et al. [12]. For the determination of titratable acidity, each of the «Dahi» samples (4.5mL) was mixed with an equal amount of distilled water and homogenized. The samples were then titrated against standardized $0.1 \mathrm{~N} \mathrm{NaOH}$ solution by using phenolphthalein indicator $(2 \mathrm{~mL})$ until the colors were changed. The percentage of titratable acidity was calculated using the following equation:

Titratable acidity $(\%)=\frac{\text { Titre value }(\mathrm{mL}) \times 0.009 \times 100}{\text { Weight of samle }(\mathrm{mL})}$

The sweetness and astringency indexes were also calculated as the ratio of soluble solids to acidity and vice versa [13].

\section{Determination of Proximate Composition}

The proximate composition of the «Dahi» samples was determined by the methods described in AOAC Method [14]. The moisture contents were determined by the moisture analyzer. The crude protein contents (Total nitrogen $(\%) \times 6.25)$ were determined by the Kjeldahl method, the crude fats were estimated by extracting known weight of samples with ethyl ether as the solvent, using a Soxhlet apparatus. Ash contents were determined by igniting the samples in the muffled furnace at $550{ }^{\circ} \mathrm{C}$ (dull red) until grayish-white ash was obtained. Total carbohydrates were calculated by the difference:

$\%$ carbohydrate $=100-(\%$ moisture $+\%$ ash $+\%$ crude protein $+\%$ crude fat $)$

\section{Determination of Microbial Properties}

Total bacterial count in «Dahi» samples were measured by serial dilution method using pour plate technique as described by Wang et al. [15]. $1 \mathrm{~mL}$ of each samples were serially transferred into $9 \mathrm{~mL}$ of the sterile diluent (peptone water) with a sterile pipette and shaken 
robustly. Serial dilution was continued until $10^{5}$ dilutions were obtained. The aliquot portion $(0.1 \mathrm{~mL})$ of the appropriate dilution was plated on nutrient agar plates. The plates were incubated at $37^{\circ} \mathrm{C}$ for $48 \mathrm{~h}$ in an incubator (GSP-9080 MBE, Shanghai, China) and colony forming units per $\mathrm{mL}$ sample $(\mathrm{cfu} / \mathrm{mL})$ were estimated.

\section{Determination of Sensory Properties}

The colour, taste (mouth feel), aroma, consistency, and overall acceptability of the «Dahi» samples were analyzed. The samples $(15 \mathrm{~g})$ were placed into cups and coded randomly with three-digit random numbers and served to the panelists. Twenty panelists from the undergraduate level with knowledge of sensory analysis were selected. They evaluated the samples using a 9-point Hedonic scale at a range of 1 (extremely dislike) to 9 (extremely like). Water was given to the panelists to rinse their mouths between tasting each sample.

\section{Statistical Analysis}

All of the analyses were conducted in triplicates. Obtained data were subjected to one way analysis of variance (ANOVA) and the difference among the means were determined using the Fisher's LSD test $(\mathrm{p}<0.05)$. The Minitab Version 19.1 Statistical Software was used for data analysis and the results were presented as mean with standard deviation.

\section{Results and discussion}

\section{Physicochemical properties of «Dahi»}

The physicochemical properties of the «Dahi» samples, including pH, TSS $\left({ }^{\circ}\right.$ Brix $)$, acidity (\%), sweetness and astringency indexes are presented in Table 2. The substitution of coconut milk for cow milk at different levels resulted in irregular changes in these parameters. The $\mathrm{pH}$ of the «Dahi» samples ranged in between 4.05 to 4.33 and are significantly different $(\mathrm{p}<0.05)$. Sample A had the lowest $\mathrm{pH}$, when compared to sample B and sample $\mathrm{C}$. In commercial fermented dairy products, Lactic acid bacteria produce lactic acid during fermentation of milk- lactose, thus lowers the $\mathrm{pH}$ [16]. The result is in agreement with the previous result published by Amirah et al. [17].

TSS in fermented dairy products is the indication of availability of dry matter content $[18,19]$. Results regarding TSS $\left({ }^{\circ} \mathrm{Brix}\right)$; it is cleared that there were significant differences $(\mathrm{P}<0.05)$ among the control and coconut milk enriched «Dahi» samples. However, sample $\mathrm{C}$ had the highest TSS content followed by sample B and sample A. This variation resulted due to the contribution of additional monosaccharide (sugars) from coconut addition [20]. Similar results were reported by Priya. [21] and Belewu et al. [18] for cow, coconut, tigernut, and soybean milk assorted fermented products.

The Titratable acidity values of «Dahi» samples also varied from 0.56 to $0.64 \%$. Sample $\mathrm{C}$ reported lower acidity while Sample A and B showed no significant differences in their respective acidity values $(\mathrm{P}>0.05)$. This could be due to the secretion of acids as a co-product by fermenting microbes while utilizing lactose and glucose for their metabolic activity during fermentation. However, these values are within an average of $0.6 \%$ acidity recommended for fermented dairy products [16]. Similar findings were reported by Isanga et al. [22] who obtained TTA (\% lactic acid) value of 0.5 to 0.75 for peanut milk yoghurt. Besides, the study reported an inverse relationship between $\mathrm{pH}$ and titratable acidity, which is also supported by earlier researchers [5]. 
The Sweetness Index (SI) and the Astringency Index (AI) predicts the tartness and sweetness of the acidic foods and modifies both organoleptic and sensorial perception [13]. Foods with sweetness index greater than 19 are regarded as sweet, with less acid by taste [13]. The sweetness indexes of the «Dahi» samples ranged in between 21.95 to 26.66 and are significantly different $(\mathrm{p}<0.05)$. The sourness of the «Dahi» expresses the level of astringency produced as a result of the Production of lactic acid by the action of lactic acid bacteria using lactose as substrates [9]. However, In the case of astringency index, it is cleared that there were no significant differences $(\mathrm{P}>0.05)$ observed among all the «Dahi» samples. These results are in covenant with many previous reports published by Ndife et al. [10] and AKEEM et al. [23].

\section{Physicochemical properties of «Dahi»}

Table 2

\begin{tabular}{|c|r|r|r|}
\hline Parameters & Sample A & Sample B & Sample C \\
\hline $\mathrm{pH}$ & $4.05 \pm 0.02^{\mathrm{c}}$ & $4.22 \pm 0.02^{\mathrm{b}}$ & $4.33 \pm 0.01^{\mathrm{a}}$ \\
\hline TSS $\left({ }^{\circ}\right.$ Brix $)$ & $14.05 \pm 0.01^{\mathrm{c}}$ & $14.52 \pm 0.02^{\mathrm{b}}$ & $14.93 \pm 0.02^{\mathrm{a}}$ \\
\hline Acidity (\%) & $0.64 \pm 0.02^{\mathrm{a}}$ & $0.61 \pm 0.02^{\mathrm{a}}$ & $0.56 \pm 0.02^{\mathrm{b}}$ \\
\hline Sweetness & $21.95 \pm 0.02^{\mathrm{c}}$ & $23.82 \pm 0.01^{\mathrm{b}}$ & $26.66 \pm 0.02^{\mathrm{a}}$ \\
\hline Astringency & $0.05 \pm 0.01^{\mathrm{a}}$ & $0.04 \pm 0.01^{\mathrm{a}}$ & $0.04 \pm 0.01^{\mathrm{a}}$ \\
\hline
\end{tabular}

* Data in same raw with different letters are significantly different $(\mathrm{P}<0.05) . \mathrm{A}=100 \%$ cow milk dahi, $\mathrm{B}=50 \%$ cow milk $+50 \%$ coconut milk dahi, $\mathrm{C}=100 \%$ coconut milk dahi

\section{Proximate composition of «Dahi»}

The proximate composition of food exerts substantial influences on their physical, nutritional, and sensorial characteristics [24, 25]. Results regarding proximate composition, all the three «Dahi» samples have shown significant differences $(\mathrm{P}<0.05)$ in the case of all parameters evaluated in this study (Table 3). Sample $\mathrm{C}$ had the highest moisture content $(85.20 \%)$ followed by Sample B $(83.49 \%)$ and Sample A $(82.75 \%)$. These values fall within the acceptable moisture content of $80-86 \%$ for fruit yoghurt stated by Ndife et al. [10]. This variation was reported due to the proportion of cow milk to coconut milk used in this study.

The protein content of «Dahi» samples varied from 2.98 to $3.13 \%$. The result depicted that protein content decreased as the proportion of the coconut-milk increased. Sample A reported comparably higher protein value $(3.13 \%)$, followed by sample B $(3.07 \%)$ and sample $\mathrm{C}(2.98 \%)$. The result is in agreement with the result published by Amirah et al. [17]. The possible reason for the difference might be denaturation of protein due to heat treatment and homogenizing process of coconut milk [26].

The fat content of «Dahi» samples ranged from 2.31 to $3.06 \%$ in the coconut enriched dahi samples when compared to control $(1.57 \%)$. The medium-chain fatty acid profile of coconut milk has promptly influenced the fat content of coconut enriched «Dahi» samples. Increased fat in coconut may not lead to heart diseases, as it contains several phytocompounds [27]. Besides, the fat contents of the enriched «Dahi» samples were within the standard $(<3.5 \%)$ for low-fat fermented dairy products [28].

The ash content also increased as the proportion of coconut-milk increased in the «Dahi» samples. This could be due to the higher minerals of coconut by implication reported by Imele and Atemnkeng. [29]. Obtained results are in agreement with results on other plant 
substituted fermented dairy products published by other researchers Belewu et al. [18] and Eke et al. [16]. The carbohydrate content of the dahi samples decreased with coconut supplementation from $11.85 \%$ in sample A to $9.50 \%$ and $5.82 \%$ in Sample B and Sample C, respectively. A similar result was also reported by Ndife et al. [10].

\section{Proximate composition of «Dahi»}

Table 3

\begin{tabular}{|c|c|c|c|}
\hline Parameters & Sample A & Sample B & Sample C \\
\hline Moisture (\%) & $82.75 \pm 0.01^{\mathrm{c}}$ & $83.49 \pm 0.02^{\mathrm{b}}$ & $85.20 \pm 0.02^{\mathrm{a}}$ \\
\hline $\operatorname{Ash}(\%)$ & $0.71 \pm 0.02^{\mathrm{c}}$ & $1.63 \pm 0.01^{\mathrm{b}}$ & $2.94 \pm 0.02^{\mathrm{a}}$ \\
\hline Fat $(\%)$ & $1.57 \pm 0.02^{\mathrm{c}}$ & $2.31 \pm 0.02^{b}$ & $3.06 \pm 0.01^{\mathrm{a}}$ \\
\hline Protein $(\%)$ & $3.13 \pm 0.01^{\mathrm{a}}$ & $3.07 \pm 0.01^{\mathrm{b}}$ & $2.98 \pm 0.01^{\mathrm{c}}$ \\
\hline Carbohydrate (\%) & $11.85 \pm 0.01^{\mathrm{a}}$ & $9.50 \pm 0.02^{b}$ & $5.82 \pm 0.01^{\mathrm{c}}$ \\
\hline
\end{tabular}

\section{Sensorial properties of «Dahi»}

Table 4 illustrated the mean scores of the sensorial and organoleptic evaluation for the different «Dahi» samples. The statistical analysis exposed that there were significant differences $(\mathrm{p}<0.05)$ among the samples $(\mathrm{A}, \mathrm{B}$ and $\mathrm{C})$ in all the observed attributes. Colour determines initial acceptability and purchasing patterns by potential consumers [30]. Sample A had the highest score (8.17), while sample $\mathrm{C}$ had the lowest score (7.35) for colour. The panelists showed a preference for the lighter colour of sample A, as coconut enrichment might have darkened the colour a little bit.

The enrichment of the «Dahi» with coconut milk resulted in better consistency and a more pronounced aroma. Sample $\mathrm{C}$ had the highest scores of 7.45 for aroma followed by sample A (7.42) and sample B (7.39), while sample B had the highest scores of 7.89 for consistency attribute followed sample C (7.86) and sample A (7.84). Most of the panelists appreciated the enriched aroma, which was attributed due to the oil content of coconut. A previous study reported that fat content considerably influences the sensorial characteristics of fermented yoghurts, as oil acts as an aroma solvent and promotes better rheological properties [28]. There were significant differences in terms of taste profile for the three samples, while sample C was rated lower in scores (7.45) than sample B (7.56) and sample A (7.82), and this was due to the flavor associated with coconut. However, higher carbohydrate content may impart in the increased sweetness of fermented products [31].

The overall acceptability rating measures the consumers' degree of likings and preferences in relation to the control sample. The highest overall acceptability means a score of 8.03 was recorded for the control (sample A), which was closely followed by coconut substituted samples C (7.96) and B (7.79). This might be due to that all the panelists were used to fermented dairy products rather than fruit-based fermented dairy products, which might have influenced their degree of likings for overall acceptability. Previous studies on coconut substitution in fermented yoghurt showed similar preferences as well [23, 31]. 
Sensorial properties of «Dahi»

\begin{tabular}{|l|l|l|l|}
\hline \multicolumn{1}{|c|}{ Parameters } & Sample A & Sample B & Sample C \\
\hline Colour & $8.17 \pm 0.02^{\mathrm{a}}$ & $7.64 \pm 0.02^{\mathrm{b}}$ & $7.35 \pm 0.01^{\mathrm{c}}$ \\
\hline Taste (Mouthfeel) & $7.82 \pm 0.02^{\mathrm{a}}$ & $7.56 \pm 0.02^{\mathrm{b}}$ & $7.45 \pm 0.02^{\mathrm{c}}$ \\
\hline Aroma & $7.42 \pm 0.01^{\mathrm{b}}$ & $7.39 \pm 0.01^{\mathrm{c}}$ & $7.45 \pm 0.01^{\mathrm{a}}$ \\
\hline Consistency & $7.84 \pm 0.02^{\mathrm{c}}$ & $7.89 \pm 0.01^{\mathrm{a}}$ & $7.86 \pm 0.02^{\mathrm{b}}$ \\
\hline Overall acceptability & $8.03 \pm 0.01^{\mathrm{a}}$ & $7.79 \pm 0.01^{\mathrm{c}}$ & $7.96 \pm 0.02^{\mathrm{b}}$ \\
\hline
\end{tabular}

*Data in same raw with different letters are significantly different $(\mathrm{P}<0.05) . \mathrm{A}=100 \%$ cow milk dahi, $\mathrm{B}=50 \%$ cow milk $+50 \%$ coconut milk dahi, $\mathrm{C}=100 \%$ coconut milk dahi

\section{Microbial Properties of «Dahi»}

Table 5 demonstrated a significant decrease in the total bacterial count while substituting cow milk with coconut milk $(\mathrm{p}<0.05)$. Sample A had the highest microbial load $\left(5.34 \pm 0.01 \times 10^{5} \mathrm{cfu} / \mathrm{ml}\right)$ followed by sample B $\left(4.87 \pm 0.02 \times 10^{5} \mathrm{cfu} / \mathrm{ml}\right)$ and sample C $\left(4.51 \pm 0.01 \times 10^{5} \mathrm{cfu} / \mathrm{ml}\right)$. The microbial status of all the «Dahi» samples was within the acceptable standard $\left(<1 \times 10^{6} \mathrm{cfu} / \mathrm{ml}\right)$ for fermented dairy products $[32,25]$.

Microbial properties of «Dahi»

Table 5

\begin{tabular}{|c|c|c|c|}
\hline Parameters & Sample A & Sample B & Sample C \\
\hline TBC $(\mathrm{cfu} / \mathrm{ml})$ & $5.34 \pm 0.01 \times 10^{5 \mathrm{a}}$ & $4.87 \pm 0.02 \times 105^{\mathrm{b}}$ & $4.51 \pm 0.01 \times 10^{5} \mathrm{c}$ \\
\hline
\end{tabular}

$*$ Data in same raw with different letters are significantly different $(\mathrm{P}<$ $0.05) . \mathrm{A}=100 \%$ cow milk dahi, $\mathrm{B}=50 \%$ cow milk $+50 \%$ coconut milk dahi, $\mathrm{C}=100 \%$ coconut milk dahi

\section{Conclusion}

The results found in this study indicate that it is feasible to use coconut milk in «Dahi» production, which should be of economic importance since it is relatively inexpensive as well. The coconut enriched «Dahi» was found to have good nutritional value. It may enhance the health benefits of the fermented product, especially those related to lactose intolerants and cardiovascular health. Hence it can be recommended as a promising substitute for «Dahi» made with cow milk. As coconut milk reduced the sensory scores of the «Dahi» in particular attributes, flavoring agents might be used to improve its sensorial acceptability in future development. Future investigation should be carried out in assessing the storage stability of «Dahi» enriched with coconut milk.

Acknowledgements. The authors are grateful to the Department of Food Processing and Engineering, Faculty of Food Science and Technology, Chattogram Veterinary and Animal Sciences University, Khulshi, Chattogram4225, Bangladesh and Faculty of Fisheries and Food Science, Universiti Malaysia Terengganu, 21300 Kuala Terengganu, Terengganu, Malaysia for providing laboratory facilities and technical support during this research work. 


\section{References}

1. Tull A. (1997), Food and nutrition, Oxford University Press, USA, pp. 109-111.

2. Bystron J., Molenda J. (2004), The Role of Lactic Acid Bacteria in Preservation of Fermented Meat Product, Krajowa Izba Lekarsko Weternaryjna publishers, Weterynaryjne, 79, pp. 688-690.

3. Harun-ur-Rashid M., Togo K., Ueda M., Miyamoto T. (2007), Probiotic characteristics of lactic acid bacteria isolated from traditional fermented milk "Dahi" in Bangladesh, Pakistan J. Nutr, 6, pp. 647-652.

4. Sethi S., Tyagi S.K., Anurag R.K. (2016), Plant-based milk alternatives an emerging segment of functional beverages: a review, Journal of food science and technology, 53(9), pp. 3408-3423.

5. Kayode R.M., Joseph J.K., Adegunwa M.O., Dauda A.O., Akeem S.A., Kayode B.I., Babayeju A.A., Olabanji, S.O. (2017), Effects of addition of different spices on the quality attributes of tiger-nut milk (kunun-aya) during storage, Journal of Microbiology, Biotechnology and Food Sciences, 7(1), pp. 1-6.

6. Belewu M.A., Belewu, K.Y. (2007), Comparative physico-chemical evaluation of tigernut, soybean and coconut milk sources, International Journal of Agriculture and Biology, 5(785), p.p 787.

7. Nieuwentus R., Nieuwelink J. (2002), Agrodok Series No. 10 CTA: The Netherlands.

8. Alyaqoubi S., Abdullah A., Samudi M., Abdullah N., Addai, Z.R., Musa, K.H. (2015), Study of antioxidant activity and physicochemical properties of coconut milk (Pati santan) in Malaysia, Journal of Chemical and Pharmaceutical Research, 7(4), pp. 967973.

9. Sanful R.E. (2009), Promotion of coconut in the production of yoghurt, African Journal of Food Science, 3(5), pp. 147-149.

10. Ndife J., Idoko F., Garba, R. (2014), Production and quality assessment of functional yoghurt enriched with coconut, International Journal of Nutrition and Food Sciences, 3(6), pp. 545-550.

11. Kolapo A.L., Olubamiwa, A.O. (2012), Effect of different concentrations of coconut milk on the chemical and sensory properties of soy-coconut milk based yoghurt, Food and Public Health, 2(4), pp. 85-91.

12. Hamad M.N.E.F., Ismail M.M., Elraghy E.M. (2017), Impact of Addition Tamr and Honey on Chemical Composition, Starter Activity and Rheological Properties of Goat's Milk, American Journal of Food Science and Nutrition, 4(3), pp. 17-22.

13. Wardy W., Saalia F.K., Steiner-Asiedu M., Budu A.S., Sefa-Dedeh, S. (2009), A comparison of some physical, chemical and sensory attributes of three pineapple (Ananas comosus) varieties grown in Ghana, African Journal of Food Science, 3(4), pp. 094-099.

14. (2007), AOAC Official Methods of Analysis, 17th ed., Association. of Official Analytical Chemists, Washington, D.C.

15. Wang J., Guo Z., Zhang Q., Yan L., Chen Y., Chen X., LIU X.M., Chen, W., ZHANG, H.P. (2010), Effect of probiotic Lactobacillus casei Zhang on fermentation characteristics of set yogurt, International journal of dairy technology, 63(1), pp. 105112.

16. Eke M.O., Olaitan N.I., Sule, H.I. (2013), Nutritional evaluation of yoghurt-like product from baobab (Adansonia digitata) fruit pulp emulsion and the micronutrient content of baobab leaves, Advance Journal of Food Science and Technology, 5(10), pp. 12661270. 
17. Amirah A.S., Nor Syazwani S., Radhiah S., Anis Shobirin M.H., Nor-Khaizura M.A.R., Wan Zunairah W.I., a Shazini, N.R. (2020), Influence of raisins puree on the physicochemical properties, resistant starch, probiotic viability and sensory attributes of coconut milk yogurt, Food Research, 4(1), pp. 77-84.

18. Belewu M.A., Belewu K.Y., Bamidele, R.A. (2010). Cyper-coconut yoghurt: preparation, compositional and organoleptic qualities, African Journal of Food Science and Technology, 1(1), pp. 010-012.

19. Khalifa M.E.A., Elgasim A.E., Zaghloul A.H., Mahfouz, M.B. (2011). Applications of inulin and mucilage as stabilizers in yoghurt production, American Journal of Food Technology, 6(1), pp. 31-39.

20. Alakali J.S., Okonkwo T.M., Iordye E.M. (2008), Effect of stabilizers on the physicochemical and sensory attributes of thermized yoghurt, African Journal of Biotechnology, 7(2), pp. 158-163.

21. Priya S.R. (2016), Preparation and Quality Assessment of Yoghurt Prepared from Dairy Milk and Coconut (Cocos nucifera, L) Milk, CORD, 32(1), pp. 10-10.

22. Isanga J., Zhang G.N. (2007). Preliminary investigation of the production and characterization of peanut milk based stirred yoghurt, International Journal of Dairy Science, 2(3), pp. 207-216.

23. Akeem S.A., Yerumoh O., Leigh O., Bamgbala K., Okeke G., Sokunbi F., Olayiwola I. (2018), Physicochemical properties, colour characteristics, and sensory evaluation of full-cream cow-coconut milk yoghurts, Croatian journal of food science and technology, 10(2), pp. 226-233.

24. Natalia P. (2009), Study regarding some physicalchemical characteristics of the yoghurt with red beetroot juice, Carpathian Journal of Food Science and Technology, I (2), pp. 44-49.

25. El-Bakri J.M., El-Zubeir, I.E. (2009), Chemical and microbiological evaluation of plain and fruit yoghurt in Khartoum State, Sudan, International journal of dairy science, 4(1), pp. 1-7.

26. Sfakianakis P., Topakas E., Tzia C. (2015). Comparative study on high-intensity ultrasound and pressure milk homogenization: Effect on the kinetics of yogurt fermentation process, Food and bioprocess technology, 8(3), pp. 548-557.

27. Sheela D.L., Nazeem P.A., Narayanankutty A., Manalil J.J., Raghavamenon, A.C. (2016), In silico and wet lab studies reveal the cholesterol lowering efficacy of lauric acid, a medium chain fat of coconut oil, Plant Foods for Human Nutrition, 71(4), pp. 410-415.

28. Saint-Eve A., Levy C., Le-Moigne M., Ducruet V., Souchon, I. (2008), Quality changes in yogurt during storage in different packagingmaterials, Food chemistry, 110(2), pp. 285-293.

29. Imele H., Atemnkeng, A. (2001), Preliminary study of the utilisation of coconut in yoghurt production, Journal of Food Technology in Africa, 6(1), pp. 11-12.

30. Tárrega A., Costell E. (2007), Colour and consistency of semi-solid dairy desserts: Instrumental and sensory measurements, Journal of Food Engineering, 78(2), pp. 65566.

31. Gad A.S., Kholif A.M., Sayed A.F. (2010), Evaluation of the nutritional value of functional yogurt resulting from combination of date palm syrup and skim milk, American Journal of Food Technology, 5(4), pp. 250-259.

32. Lourens-Hattingh A., Viljoen B.C. (2001), Yogurt as probiotic carrier food, International dairy journal, 11(1-2), pp. 1-17. 